- FINANSE I PRAWO FINANSOWE.

- Journal of Finance and Financial Law $•$

Grudzień/December 2019 • vol. 4(24): 33-48

http://dx.doi.org/10.18778/2391-6478.4.24.03

\title{
ZJAWISKO SZAREJ STREFY W POLSCE - PRZYCZYNY, SKUTKI I METODY OGRANICZANIA
}

\author{
Sara Franciszkowska \\ Anna Węgrzyn \\ Wydział Ekonomiczno-Socjologiczny, Uniwersytet Łódzki
}

\begin{abstract}
Streszczenie
Artykuł dotyczy szarej strefy, rozumianej jako wszelkie próby unikania obowiązku podatkowego przez obywateli. Zjawisko to jest nieodłączną częścią każdej gospodarki i może na nią wpływać zarówno w sposób pozytywny, jak i negatywny, przy czym udział niekorzystnych konsekwencji jest większy. Mając to na uwadze, władze państwowe podejmują szereg działań, mających na celu ograniczanie zasięgu szarej strefy. Istotnym elementem w kształtowaniu się jej rozmiarów jest to, czy obywatele wyrażają "ciche przyzwolenie" na tego typu czynności. Opracowanie zawiera badanie na temat poziomu moralności podatkowej wśród losowo wybranej grupy badanych w wieku produkcyjnym.
\end{abstract}

Słowa kluczowe: szara strefa, podatki, oszustwa podatkowe.

JEL Class: E26, H26. 


\section{WPROWADZENIE}

Jednym z instrumentów umożliwiającym oddziaływanie władz państwowych na gospodarkę jest szeroko rozumiany podatek, stanowiący główne źródło dochodu publicznego. To pojęcie można rozumieć jako świadczenie pieniężne na rzecz związku publicznoprawnego, któremu towarzyszy przewłaszczenie generalne, obowiązkowe, przymusowe, ustalane jednostronnie, nieodpłatne, nieekwiwalentne i bezzwrotne [Dzwonkowski 2011]. Każde naruszenie tego źródła dochodu oznacza spadek wydajności podatków, a w konsekwencji pociąga za sobą niższe wpływy do budżetu [Jaszczyński 2017]. Wraz z pojawieniem się pierwszych podatków, zaczęto szukać sposobu na unikanie ich płacenia i w związku z powyższym powstało zjawisko znane jako szara strefa, które będzie stanowiło przedmiot rozważań artykułu.

Po raz pierwszy tego określenia użył brytyjski uczony Keith Hart w pracy poświęconej formalnym i nieformalnym możliwościom zarobku w Ghanie w 1971 r. [Szulc 2013: 9]. Pojęcie to można rozumieć jako całokształt form niezarejestrowanej działalności gospodarczej, niezależnie od tego czy są one legalne (jak samozaopatrzenie gospodarstw domowych), czy nielegalne (jak sfingowana produkcja narkotyków itp.) [Mizgajska 2002]. Innymi słowy, szarą strefę stanowią wszystkie uszczuplenia budżetu państwa, wynikające $\mathrm{z}$ uchylania się obywateli od obowiązku podatkowego.

Celem opracowania jest przedstawienie pojęcia „szarej strefy” i jego składowych, wyodrębnienie zarówno pozytywnych jak i negatywnych konsekwencji (takich jak stwarzanie zagrożenia dla legalnie działających przedsiębiorstw w postaci nieuczciwej konkurencji, obniżenie wpływów do budżetu państwa). Artykuł wieńczą przedstawione metody ograniczania zasięgu szarej strefy i case study polskiej świadomości podatkowej wśród osób w wieku produkcyjnym.

Przyjęto hipotezę, że stosowanie prawnych i pozaprawnych instrumentów przez władzę danego kraju, wpływa na zmniejszanie się rozmiarów szarej strefy. Mimo faktu, że w gospodarkach rynkowych istnienie drugiego obiegu jest „naturalne", to należy pamiętać o tym, że gdy skala drugiego obiegu jest mała, to nie zakłóca ona funkcjonowania gospodarki narodowej. (...) Problem pojawia się, gdy dochodzi do nadmiernego rozwoju działalności szarej strefy [Korenik i Korenik 2004: 74], dlatego tak bardzo istotne jest stosowanie różnych procedur uniemożliwiających działania przeciwko powszechnemu obowiązkowi podatkowemu. Opracowanie powstało $\mathrm{w}$ oparciu o literaturę przedmiotu, raporty, regulacje prawne i własne badania. 


\section{POJĘCIE I ZAKRES SZAREJ STREFY}

Temat gospodarki nieoficjalnej jest wielokrotnie poruszany w literaturze naukowej oraz nagłaśniany $\mathrm{w}$ środkach masowego przekazu. Można spotkać różne określenia dla identyfikacji tego zjawiska, takie jak rynek równoległy, szara strefa (shadow economy), drugi obieg gospodarczy (non-observed market), rynek nieoficjalny (unofficial economy), podziemie gospodarcze (informal market) [Masiukiewicz 2014: 29]. Żadne z użytych określeń wzajemnie sobie nie przeczą, a wręcz przeciwnie - wzbogacają, ujawniają wieloaspektowość tego typu gospodarki [Kozłowski 2004], jednakże równocześnie taka mnogość synonimów, a w konsekwencji znaczeń na określenie gospodarki innej od tej prowadzonej w warunkach legalnych, prowadzi do zbytnich i niewłaściwych uogólnień w zakresie klasyfikacji tego, co stanowi gospodarka nieoficjalna [Raczkowski 2013: 353]. Z tego też powodu w opracowaniu ograniczono się do terminu szarej strefy, ponieważ jest to jedno z najczęściej spotykanych sformułowań w publicystyce.

Gospodarkę nieoficjalną charakteryzuje bogactwo form i przejawów występowania [Mróz 2004: 249], przez to przechodząc do samej definicji w literaturze przedmiotu można spotkać węższe i szersze ujęcie zjawiska unikania obowiązku podatkowego. Zgodnie z jednym $\mathrm{z}$ nich, uchylanie się od podatku jest zawsze działaniem nielegalnym, sprzecznym z prawem podatkowym [Głuchowski 2006: 158]. Jednakże w szerokim wymiarze można to rozumieć, jako wszelkie działania gospodarcze, które przyczyniają się do oficjalnego (albo obserwowalnego) tworzenia (wzrostu) PKB, ale które pozostają bezpośrednio niezarejestrowane [Schneider i Enste 2000]. Tak samo Raport Instytutu Prognoz i Analiz „Szara strefa 2018” określa ją ogólnie jako działalność gospodarczą, prowadzoną poza oficjalnym obiegiem, podlegającym kontroli państwa. Poszczególne składowe stanowiące czynności gospodarcze należące do działalności w ramach szarej strefy przedstawia schemat 1 .

Łatwo zauważyć, że wspólnym elementem powyższych definicji jest zatajony charakter badanego zjawiska, gdyż stanowi on jego fundamentalną cechę oraz należy pamiętać, że podstawowym kryterium zaliczania działalności gospodarczych do szarej strefy jest tworzenie wartości dodanej, która umyka tradycyjnej obserwacji statystycznej prowadzonej przez narodowe urzędy statystyczne. Należy przez to rozumieć rynkowy i dobrowolny charakter transakcji [Łapiński i in. 2014: 8].

Powszechnie przyjmuje się podział szarej strefy na trzy obszary:

I. Działalność nielegalna;

II. Działalność ukryta;

III. Działalność nieformalna. 


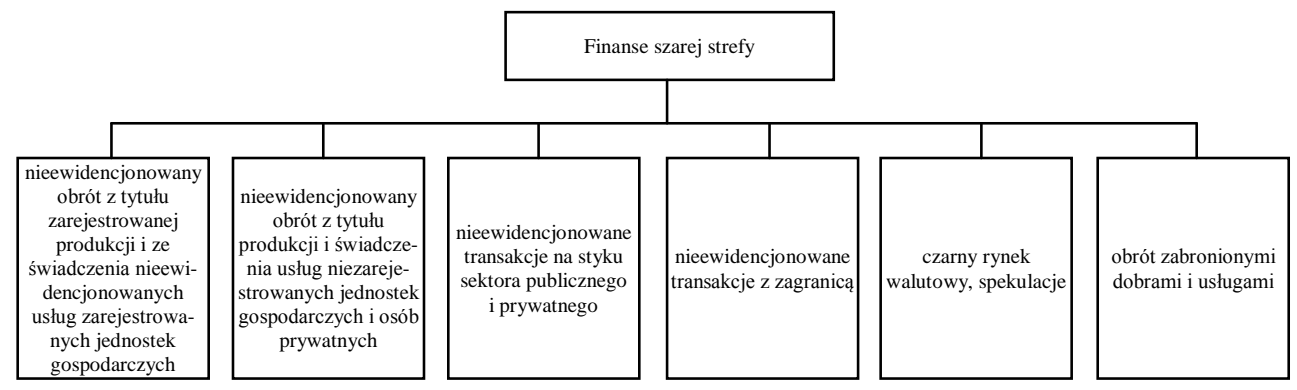

Schemat 1 . Elementy finansów szarej strefy

Źródło: opracowanie własne na podstawie Korenik i Korenik [2004].

Tabela 1. Szacunki rozmiarów gospodarki nieobserwowanej w tworzeniu PKB w latach 2012-2015 (w proc.)

\begin{tabular}{|l|c|c|c|c|}
\hline Elementy szarej strefy & 2012 & 2013 & 2014 & 2015 \\
\hline Działalność ukryta & 9,6 & 10,6 & 10,4 & 11,0 \\
\hline Działalność nieformalna & 2,6 & 2,4 & 2,3 & 2,2 \\
\hline Działalność nielegalna & 0,8 & 0,8 & 0,6 & 0,3 \\
\hline Gospodarka nieobserwowana & 13,0 & 13,8 & 13,3 & 13,5 \\
\hline Ogółem & $\mathbf{2 6}$ & $\mathbf{2 7 , 6}$ & $\mathbf{2 6 , 6}$ & $\mathbf{2 7}$ \\
\hline
\end{tabular}

Źródło: Fundowicz i in. [2018].

Pierwszym elementem szarej strefy gospodarczej jest działalność nielegalna, obejmująca produkcję wyrobów i usług, których sprzedaż, rozprowadzanie lub posiadanie jest zabronione przez prawo [Fundowicz i in. 2018: 6] i w związku z tym ponosi się za nią odpowiedzialność karną. Najczęściej jest związana z przemytem dóbr (np. papierosów), produkcją i handlem narkotykami, czy sutenerstwem lub z działalnością legalną prowadzoną przez osoby niemające do niej uprawnień.

Drugi obszar dotyczy działalności legalnej, lecz zatajonej. Chodzi tu o zaniżanie obrotów, głównie celem obniżenia uciążliwości wynikających z opodatkowania. Inny powód ukrywania części produkcji dóbr lub usług, to niewypełnienie standardów wymaganych przez przepisy prawa. Panuje generalna zasada, że zjawisko to jest bardziej powszechne wśród mikro- i małych przedsiębiorstw niż wśród średnich i dużych, chociaż zdarzają się wyjątki [Łapiński i in. 2014: 10]. Często niskie zyski działalności gospodarczych i wysokie zobowiązania uniemożliwiają przedsiębiorcom dostosowanie się do wprowadzonych wyższych stóp procentowych podatku i nowego wynagrodzenia minimalnego, 
dlatego aby utrzymać zarówno zatrudnienie, jak i produkcję na niezmienionym poziomie, zatajają część przychodów przed organem podatkowym.

Ostatni podział na działalność nieformalną uwzględnia transakcje, do których nie prowadzi się żadnych rejestrów i podejmowana jest głównie przez osoby fizyczne, odpłatnie świadczące usługi na rzecz innych osób, czasem także na rzecz przedsiębiorstw. Całkowity brak bezpośredniej rejestracji jest albo wynikiem małej skali działalności, albo działaniem z pominięciem regulacji i standardów, może wynikać również z dorywczego bądź sezonowego charakteru podejmowanych przedsięwzięć [Fundowicz i in. 2018: 6].

\section{SKUTKI WYSTĘPOWANIA SZAREJ STREFY}

Szara strefa ma istotne oddziaływanie społeczne, ponieważ jest silnie powiązana z szeregiem negatywnych zjawisk, takich jak korupcja, przestępstwa różnego rodzaju, narkotyki, mafia, wykorzystanie potencjalnej siły roboczej na czarnym rynku do prania pieniędzy i naruszanie praw człowieka [Mara 2011: 1111], ale to nie oznacza, że ta część gospodarki przynosi wyłącznie negatywne skutki dla funkcjonowania państwa. Można wyodrębnić również rozmaite pozytywne efekty występowania szarej strefy.

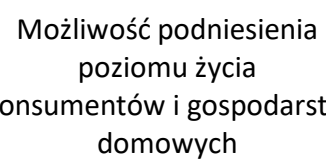

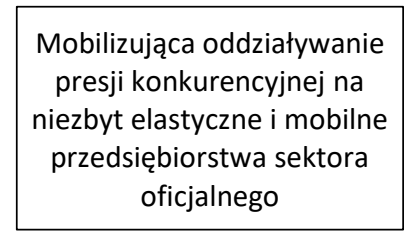
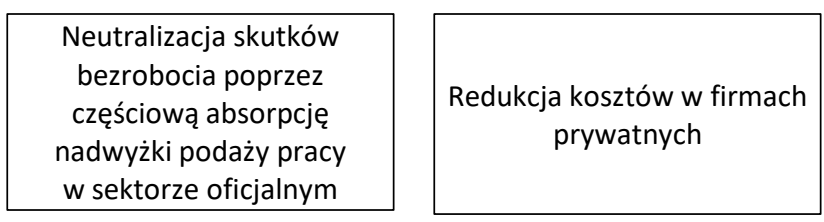

Schemat 2. Pozytywne skutki istnienia szarej strefy

Źródło: Mróz [2004].

Nie zmienia to faktu, że drugi obieg może destrukcyjnie wpływać na rozwój stosunków finansowych w kraju. Mnogość negatywnych skutków i ich skala powodują, że w znacznej mierze wpływają one na każdy obszar gospodarki i zakłócają funkcjonowanie poszczególnych instytucji. Według Ćwikowskiego negatywne następstwa można podzielić według płaszczyzny makro i mikroeko- 
nomicznej. Do pierwszej kategorii możemy zaliczyć wszystkie te zjawiska, które dotyczą całej społeczności i których skutki wpłyną na zmianę wielkości makroekonomicznych, natomiast druga kategoria skupia się na indywidualnym interesie jednostki.

Do zagrożeń na płaszczyźnie makro należy:

- zmniejszenie dochodów budżetowych z powodu nieodprowadzonych podatków wpływających do instytucji państwowych,

- brak możliwości realnej oceny prowadzonej polityki gospodarczej z powodu zniekształconych wskaźników gospodarczych,

- konieczność utrzymania podatków na wysokim poziomie, aby móc uzbierać wystarczające fundusze na finansowanie państwa,

- niski poziom zaufania do instytucji państwowych,

- wysoki poziom korupcji.

Do niebezpieczeństw na płaszczyźnie mikro należy:

- ograniczone możliwości rozpoczynania działalności gospodarczej z powodu nadmiernego obciążenia podatnika,

- nieuczciwa konkurencja cenowa dla legalnie funkcjonujących podmiotów,

- obniżanie zysków z legalnych przedsiębiorstw,

- brak możliwości rozwoju przedsiębiorstw,

- wysokie stopy procentowe przy udzielaniu kredytów przez banki,

- indywidualne niesprawiedliwości społeczne w ponoszeniu ciężarów na rzecz państwa, $-114]$.

- niepewność w funkcjonowaniu przedsiębiorców [Ćwikowski 2016: 113

Często można się również spotkać się z sytuacją, w której występująca szara strefa posiada charakter dwubiegunowy, co jest bardzo dobrze zauważalne w przypadku rozważań związanych z kryzysem gospodarczym.

$Z$ jednej strony według Marciniaka szara strefa gospodarcza unikająca jakichkolwiek wpłat do budżetu państwa stanowi istotny element współtworzący kryzys systemu finansów publicznych w Polsce [Marciniak 2013: 633]. Związane jest to $\mathrm{z}$ tym, iż istnieje zależność pomiędzy stopą bezrobocia w kraju, a rozmiarem gospodarki nieoficjalnej, co potwierdza wzrost szarej strefy, który wystąpił w większości krajów OECD w 2009 roku podczas kryzysu ekonomicznego [Rosser i in. 2000], ale równocześnie w przypadku wystąpienia zapaści gospodarczej stanowi pewien bufor bezpieczeństwa dla państwa i powoduje, że obywatele, szczególnie ci o najniższych zarobkach, o wiele mniej odczuwają pogorszenie stanu gospodarki. 


\section{METODY OGRANICZANIA ZASIĘGU SZAREJ STREFY}

Nowoczesny system podatkowy powinien wpływać na przemiany strukturalne, wywoływać pożądane procesy gospodarcze oraz tak kierować zachowaniem podatników, aby ograniczać zjawisko szarej strefy [Kuchciak 2012: 11] i znajduje to swoje uzasadnienie zarówno w interesie państwa, jak i przedsiębiorców. Państwo dąży do uzyskania wszystkich należnych mu wpływów do budżetu w postaci podatków. Osoby uczestniczące w szarej strefie, nielegalnie przywłaszczają sobie te wpływy, ograniczając tym samym możliwości finansowe państwa $\mathrm{w}$ zakresie działań w innych obszarach. Przedsiębiorcy i usługodawcy, którzy działają w legalny sposób, zmuszeni są do zmagania się z nieuczciwą konkurencją, choćby dlatego, że przedsiębiorcy, będący jednocześnie oszustami podatkowymi, są $\mathrm{w}$ stanie oferować produkty po niższej cenie. W związku z powyższym podjęto szereg działań, mających na celu ograniczenie zasięgu szarej strefy.

Podstawowym elementem mającym wpływ na zachowania przedsiębiorców są kary za nieprzestrzeganie prawa podatkowego. Celem prawa karnego skarbowego jest zapewnienie wykonywania zobowiązań podatkowych [Binda 2014]. Odpowiedzialność karna za przestępstwa jest jednym z głównych czynników, motywujących ludzi do podejmowania legalnych działań oraz sprawia, że podejmowanie czynności sprzecznych z prawem nie jest atrakcyjne i niesie ze sobą duże ryzyko. Przestępstwa popełniane wobec prawa w celu uniknięcia opodatkowania lub zmniejszenia jego wysokości reguluje Kodeks karny skarbowy. [Pasternak-Malicka 2016]. O wysokości kar decyduje głównie wysokość podatku narażonego na uszczuplenie.

Grożące kary za niedopełnienie obowiązku podatkowego nie wpływają na wszystkich przedsiębiorców, dlatego niezbędne jest przeprowadzanie kontroli skarbowych. Według ustawy z dnia 28 września 1991 r. o kontroli skarbowej ich głównym celem jest ochrona interesów i praw majątkowych Skarbu Państwa oraz zapewnienie skuteczności wykonywania zobowiązań podatkowych i innych należności stanowiących dochód budżetu państwa lub państwowych funduszy celowych. Wykres 1 przedstawia zależność między liczbą przeprowadzonych kontroli podatkowych a kwotami wykrytych uszczupleń podatkowych. W początkowych latach widać, że liczba kontroli była wysoka, lecz wartość wykrywanych uszczupleń była relatywnie niska. W kolejnych okresach zauważamy wyraźną zmianę tej tendencji. Mimo że liczba kontroli skarbowych maleje (z wyjątkiem roku 2016), wartość wykrywanych nieprawidłowości cały czas się zwiększa. W roku 2016 w porównaniu z rokiem 2012 liczba kontroli spadła o 303, przy jednoczesnym prawie sześciokrotnym wzroście wykrytych uszczupleń podatkowych. Wskazuje to na wzrost efektywności przeprowadzanych kontroli skarbowych i skuteczności w wykrywaniu nieprawidłowości. 


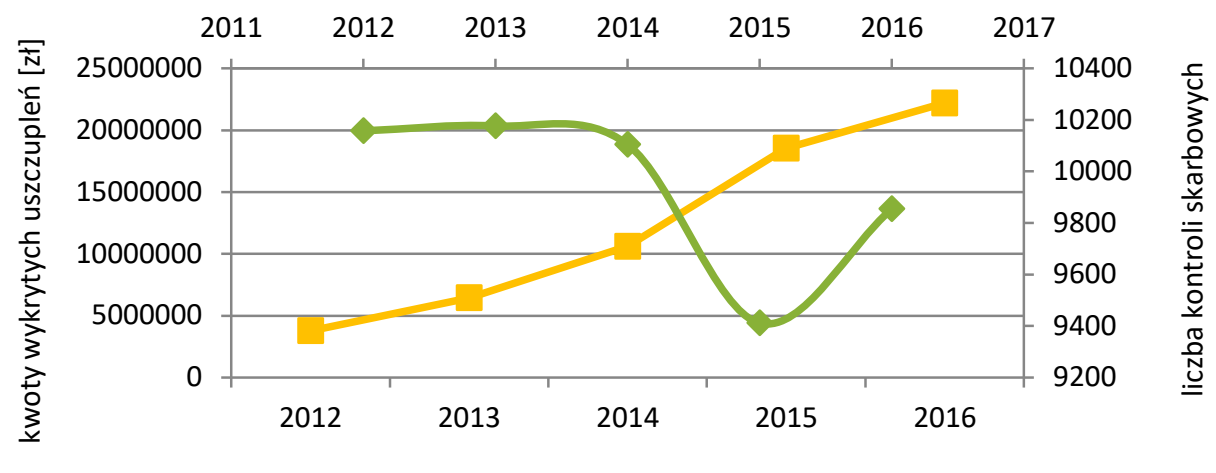

kwoty wykrytych uszczupleń podatkowych $\longrightarrow$ liczba kontroli skarbowych

Wykres 1. Zależność pomiędzy liczbą kontroli skarbowych i kwotą wykrytych uszczupleń podatkowych

Źródło: opracowanie własne na podstawie Ministerstwo Finansów - Sprawozdanie Roczne Kontrola Skarbowa w 2016 r.

Transakcje w szarej strefie odbywają się głównie za pośrednictwem gotówki, gdyż każda forma płatności bezgotówkowej zostaje zapisana w systemach płatniczych, dlatego zmniejszanie ilości fizycznej postaci pieniądza w obiegu przyczynia się w znacznym stopniu do ograniczania rozmiarów drugiej gospodarki. Transakcje bezgotówkowe mają określony górny limit przekazywanej kwoty, ustanowiony w art. 19. Ustawy z dnia 6 marca 2018 r. Prawo przedsiębiorców:

Dokonywanie lub przyjmowanie płatności związanych z wykonywaną działalnością gospodarczą następuje za pośrednictwem rachunku płatniczego przedsiębiorcy, w każdym przypadku, gdy:

- stroną transakcji, z której wynika płatność, jest inny przedsiębiorca oraz

- jednorazowa wartość transakcji, bez względu na liczbę wynikających z niej płatności, przekracza 15000 zł lub równowartość tej kwoty, przy czym transakcje w walutach obcych przelicza się na złote według średniego kursu walut obcych ogłaszanego przez Narodowy Bank Polski z ostatniego dnia roboczego poprzedzającego dzień dokonania transakcji.

Władze państwowe podejmowały się również przeprowadzania kampanii, mających na celu zwiększenie świadomości obywateli na temat prawidłowego zachowania konsumenckiego. Przykładem tego jest akcja edukacyjna ministerstwa finansów „Loteria paragonowa”, która wystartowała 1 października 2015 r. W ramach tego projektu, każdy kto dokonał zakupu o wartości powyżej 10 PLN brutto i odebrał dowód transakcji w postaci paragonu fiskalnego, mógł wziąć udział w losowaniu nagród, poprzez zarejestrowanie tego paragonu za pośred- 
nictwem odpowiedniej strony internetowej. Rozwiązanie to miało budować świadomość konsumentów odnośnie pobierania paragonów fiskalnych i tym samym „zmuszać” sprzedawców do ich wydawania i fiskalizacji obrotu [Wyżnikiewicz 2016].

\section{CASE STUDY}

\subsection{Wstęp}

Poziom moralności podatkowej wśród społeczeństwa oddziałuje na rozmiary szarej strefy. Jeśli jest niski i panuje powszechna akceptacja dla oszustw podatkowych, to przestępcy podatkowi nie czują aż tak silnej presji spełnienia obowiązku podatkowego, niż w przypadku, gdy poziom ten byłby wysoki. Istotnym elementem, który również wpływa na ustalanie się wielkości drugiej gospodarki, jest poziom wiedzy obywateli na temat prawa podatkowego oraz to, czy jest ono zrozumiałe i łatwe do zinterpretowania dla przedsiębiorców.

Biorąc pod uwagę wszechstronność tego zagadnienia i fakt, że metody szacowania wielkości szarej strefy sprowadzają się, najogólniej mówiąc, do wykorzystywania informacji gospodarczych opisujących pośrednio efekty [Fundowicz $\mathrm{i}$ in. 2018: 7], przeprowadzono badanie na panelu studentswatch w celu ustalenia bardziej rzeczywistych szacunków, o bardziej subiektywnym charakterze. Zadano szereg pytań czterystu losowym osobom w wieku produkcyjnym, zamieszkującym terytorium Polski. Ankieta składała się z 11 pytań, dotyczących wiedzy oraz doświadczeń respondentów z systemem podatkowym w Polsce. Większość z nich polegała na ocenie w 5-cio stopniowej skali osobistych poglądów lub wiedzy na temat poszczególnych zagadnień związanych z podatkami. Wyniki badania przedstawiono opisowo oraz graficznie w postaci wykresów i tabel. Badanie trwało od 10 do 21 marca 2019 roku.

\subsection{Wyniki przeprowadzonych badań ankietowych}

Poziom swojej wiedzy na temat prawa podatkowego w Polsce ankietowani oceniają jako umiarkowany (42\%) oraz mały $(37,3 \%)$. Jedynie $2,5 \%$ badanych deklaruje, że bardzo dobrze zna tę tematykę. Podobnie rezultaty kształtują się w odpowiedziach na pytanie o znajomość kar za przestępstwa i wykroczenia skarbowe. Ponadto więcej niż połowa osób twierdzi, że w ogóle nie interesuje się tematyką prawa podatkowego lub interesuje się tym w małym stopniu. Okazuje się też, że jedynie $2 \%$ badanych uważa, że bardzo dobrze rozumie prawo podatkowe obowiązujące w Polsce. 
Tabela 2. Zestawienie odpowiedzi na pytania

\begin{tabular}{|c|c|c|c|c|c|}
\hline \multirow{2}{*}{ Pytanie } & \multicolumn{5}{|c|}{ Odpowiedzi [\%] } \\
\cline { 2 - 6 } & $\begin{array}{c}\text { w ogóle nie } \\
\text { znam/ } \\
\text { nie interesuję się }\end{array}$ & $\begin{array}{c}\text { w małym } \\
\text { stopniu }\end{array}$ & $\begin{array}{c}\text { w umiarkowa- } \\
\text { nym stopniu }\end{array}$ & $\begin{array}{c}\text { w znacznym } \\
\text { stopniu }\end{array}$ & $\begin{array}{c}\text { bardzo dobrze } \\
\text { znam/interesuję } \\
\text { się }\end{array}$ \\
\hline $\begin{array}{c}\text { Jak Pan/i ocenia } \\
\text { poziom swojej } \\
\text { wiedzy o syste- } \\
\text { mie podatkowym } \\
\text { w Polsce? }\end{array}$ & 8,5 & 37,3 & 42 & 9,8 & 2,5 \\
\hline $\begin{array}{c}\text { Jak ocenia } \\
\text { Pan/i poziom } \\
\text { swojej wiedzy na } \\
\text { temat kar obo- } \\
\text { wiązujących za } \\
\text { wykroczenia i } \\
\text { przestępstwa } \\
\text { skarbowe? }\end{array}$ & 14 & 36,3 & 35,8 & 11,8 & 2,3 \\
\hline $\begin{array}{c}\text { Czy interesuje się } \\
\text { Pan/i tematyką } \\
\text { finansowo- } \\
\text { podatkową? }\end{array}$ & 22 & 33,5 & 30,8 & 10,8 & \\
\hline $\begin{array}{c}\text { Jak ocenia } \\
\text { Pan/i trudność } \\
\text { zrozumienia } \\
\text { polskiego prawa } \\
\text { podatkowego? }\end{array}$ & 13,5 & 28,6 & 39,3 & 16,5 & \\
\hline
\end{tabular}

Źródło: opracowanie własne.

Uważam, że polityka podatkowa w Polsce prowadzona jest w sposób...

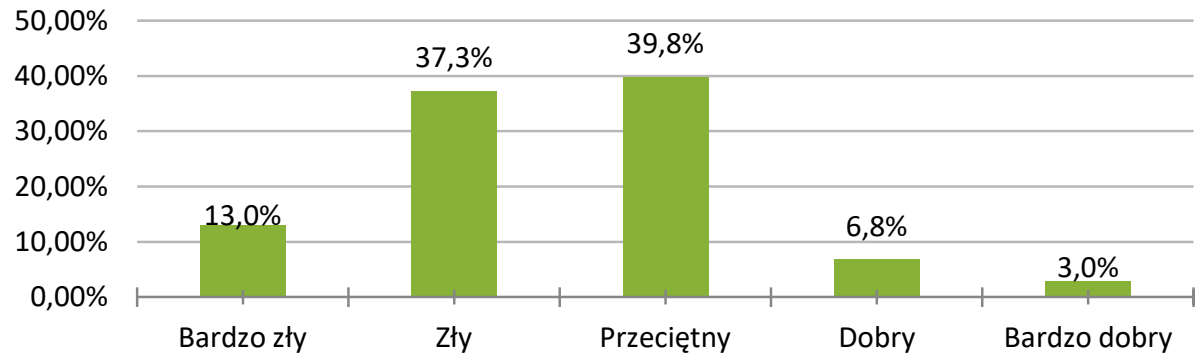

Odpowiedź

Wykres 2. Ocena prowadzenia polityki podatkowe w Polsce

Źródło: opracowanie własne. 
Poziom prowadzonej polityki podatkowej w Polsce najczęściej uznawany jest za przecięty $(39,8 \%)$ oraz zły $(37,3 \%)$, a połowa badanych $(50,3 \%)$ nie jest zadowolona $\mathrm{z}$ obecnie prowadzonej polityki podatkowej, mimo wcześniej zadeklarowanej niskiej wiedzy na ten temat.

Jako główny powód występowania szarej strefy, najczęściej wybierano zbyt wysokie podatki. Znajduje to swoje odzwierciedlenie przy pytaniu o ocenę wysokości podatków w Polsce. Prawie połowa osób (45,5\%) uznała je za wysokie.

Z poniżych odpowiedzi proszę wybrać tę, która według Pana/i stanowi główną przyczynę powstawania "szarej strefy" w Polsce

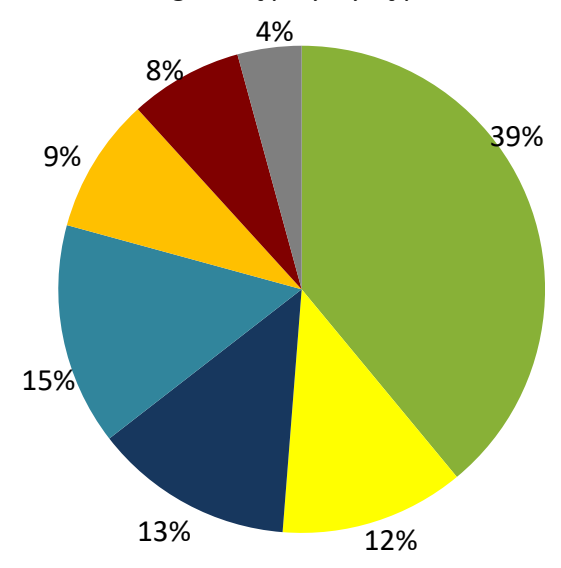

Za wysokie podatki

Nieszczelny system podatkowy

Zbyt niska świadomość podatkowa w społeczeństwie

- Korupcja

Zbyt skomplikowane prawo podatkowe

Zbyt niskie kary za wykroczenia i przestępstwa podatkowe

- Przestępczość zorganizowana

Źródło: opracowanie własne.

Jak Pan/i ocenia wysokość podatków w Polsce ? (w skali 1-5)

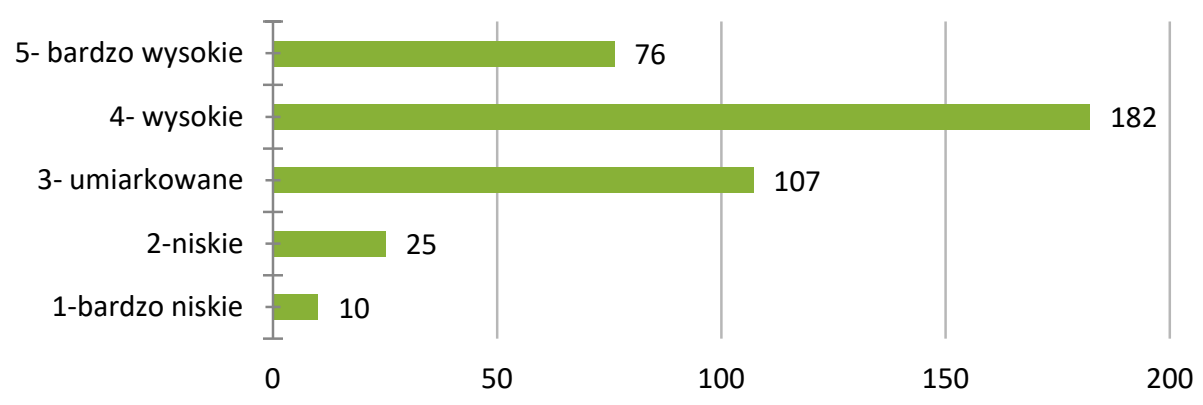

Wykres 4. Ocena wysokości podatków w Polsce

Źródło: opracowanie własne. 
W kolejnej części ankiety zapytano badanych, czy kiedykolwiek oni lub ktoś z ich otoczenia podejmował się pracy na czarno oraz czy kiedykolwiek oni lub ktoś z ich otoczenia uniknął zapłaty należnego podatku. Okazało się, że wyniki w tych dwóch podobnych pytaniach nie pokrywają się.

Tabela 3. Porównanie pytań o podejmowanie pracy „na czarno” oraz unikanie zapłaty należnego podatku

\begin{tabular}{|l|c|c|}
\hline \multirow{2}{*}{ Pytanie } & \multicolumn{2}{|c|}{ Odpowiedź [\%] } \\
\cline { 2 - 3 } & tak & nie \\
\hline $\begin{array}{l}\text { Czy kiedykolwiek Pan/i lub ktoś z Pana/i otoczenia podejmował się } \\
\text { pracy bez odpowiedniej podstawy prawnej w postaci umowy? }\end{array}$ & 45,2 & 54,8 \\
\hline $\begin{array}{l}\text { Czy kiedykolwiek Pan/i lub ktoś z Pana/i otoczenia celowo lub } \\
\text { niecelowo uniknął zapłaty należnego podatku? }\end{array}$ & 29,3 & 70,7 \\
\hline
\end{tabular}

Źródło: opracowanie własne.

Poza tym, większość ankietowanych deklaruje, że zawsze przestrzega obowiązku podatkowego $(50,4 \%)$, co $\mathrm{w}$ pewnym stopniu kłóci się z pytaniem powyższym, gdzie aż $45,2 \%$ badanych potwierdziło, że samo uczestniczyło lub było świadkiem oszustw podatkowych.

Czy przestrzega Pan/i swojego obowiązku podatkowego?

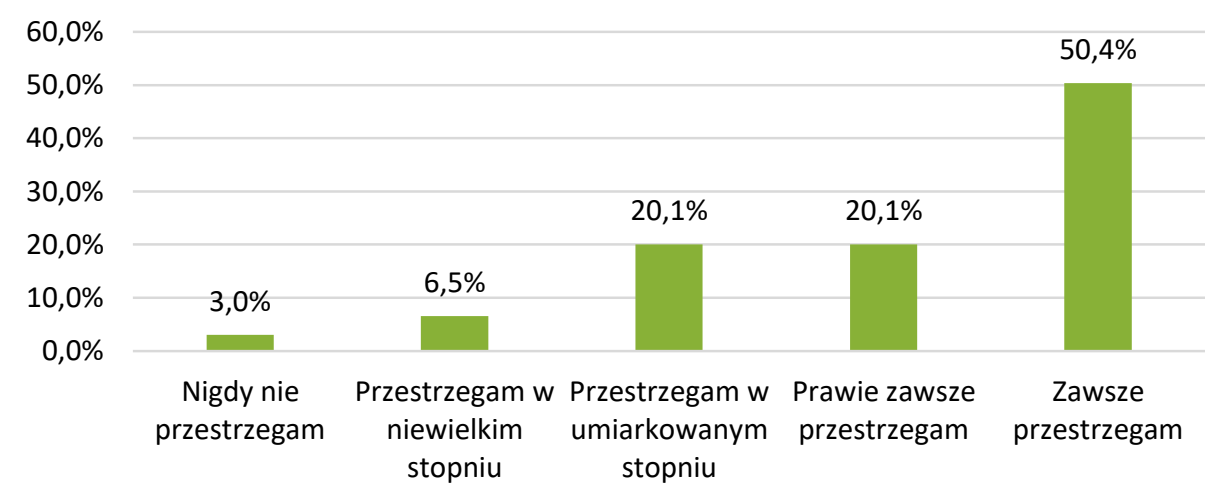

Wykres 5. Przestrzeganie obowiązku podatkowego

Źródło: opracowanie własne.

Większość badanych uważa, że unikanie płacenia podatków powinno być zawsze potępiane przez społeczeństwo. 


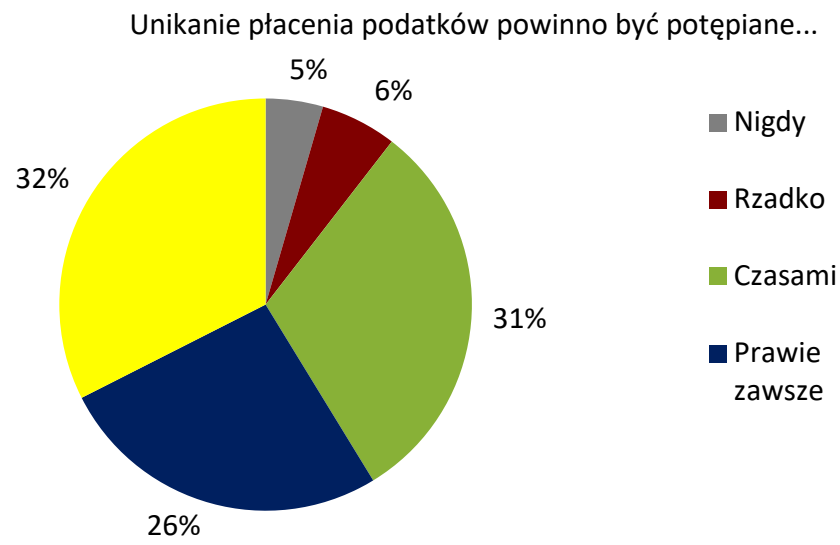

Wykres 6. Ocena unikania płacenia podatków

Źródło: opracowanie własne.

\subsection{Podsumowanie CASE STUDY}

Wiedza respondentów na temat systemu podatkowego jest przeciętna lub niska. Wynika to z braku zainteresowania tą tematyką lub trudnościami z jej zrozumieniem. Ogólny poziom prowadzonej polityki podatkowej można uznać za niezadowalający. Wśród społeczeństwa panuje przekonanie, iż stawki podatków są zbyt wysokie, co jest również najczęściej wskazywane jako główna przyczyna do unikania obowiązku regulowania zobowiązań podatkowych, a w konsekwencji do przechodzenia do szarej strefy. Brak zależności w pytaniach o podejmowanie pracy na czarno oraz nieodprowadzanie należnego podatku, może wynikać z niskiej wiedzy i niezrozumienia pytań lub braku chęci ujawnienia odpowiedzi na któreś z nich. Zaskakujące jest, że mimo wyżej wymienionych wniosków, większość ludzi deklaruje, że zawsze przestrzega swojego obowiązku podatkowego oraz uważa, że unikanie podatków powinno być potępiane zawsze lub prawie zawsze. Wskazuje to na wysoką moralność podatkową wśród badanych, wynikłą nie z wiedzy czy z doświadczenia, ale z powodu własnego systemu moralnego. Nie należy wykluczyć, że poszczególni ankieterzy mogli nie chcieć podzielić się z nami swoimi osobistymi informacji w obawie przed ujawnieniem ich do organu podatkowego. Niestety tego typu badania zawsze będą miały charakter mocno subiektywny, dlatego też chcąc obliczyć zakres szarej strefy byłoby konieczne porównanie różnych wartości ekonomicznych i z zastosowaniem metod pośrednich, dokonać szczegółowej analizy rynku pracy czy analizy porównawczej w rachunkach narodowych. 


\section{PODSUMOWANIE}

Szara strefa jest zjawiskiem funkcjonującym w każdej gospodarce, ale mimo jej powszechności, powinniśmy rozważyć jej wszystkie możliwe, zarówno korzystne, jak i szkodliwe efekty przy podejmowaniu decyzji o zastosowaniu środków ograniczających jej zasięg.

Trudno jest wyodrębnić jedną uniwersalną definicję szarej strefy, ale posługując się literaturą można wskazać, że zawierają się w niej wszystkie czynności mające na celu pozbawienie państwa należnego mu według obowiązującego prawa podatku i co najważniejsze, te starania muszą być podejmowane świadomie, aby mogły kwalifikować się do tej części gospodarki.

Władze krajowe, obserwując zwiększenie liczby osób działających w szarej strefie, mogą zdecydować się na korzystanie z różnych metod ograniczenia zakresu tego zjawiska, takich jak zwiększanie liczby i dokładności kontroli skarbowych, czy wyznaczanie odpowiedniego wymiaru kar za niedotrzymanie obowiązku podatkowego. Tego typu procedury w pewnym stopniu zmniejszają skalę tego zjawiska, jednakże biorąc pod uwagę rezultaty przeprowadzonego case study nie należy również lekceważyć aspektów społecznych i prowadzić dodatkową edukację z zakresu prawa finansowego i podatkowego. Artykuł ten może stać się podstawą do dalszych rozważań na temat zależności pomiędzy mentalnością i moralnością podatkową a wysokością środków wpływających do budżetu z tytułu podatków.

\section{BIBLIOGRAFIA}

Binda J., 2014, Przestęczość podatkowa i oszustwa finansowe zagrożeniem dla finansów publicznych w Polsce, ,Zeszyty Naukowe. Wyższa Szkoła Finansów i Prawa w Bielsku Białej”, nr 3.

Ćwikowski M., 2016, Gospodarka nieoficjalna a bezpieczeństwo ekonomiczne państwa, CeDeWu, Warszawa.

Dzwonkowski H., 2011, Prawo podatkowe, C.H. Beck, Warszawa.

Fijałkowska J., 2016, Jednolity Plik Kontrolny - elektroniczne raportowanie a uszczelnianie systemu VAT, „Studia i Prace Kolegium Zarządzania i Finansów. Zeszyt Naukowy”, nr 158.

Fundowicz J., Łapiński K., Wyżnikiewicz B., 2018, Szara strefa 2018, Warszawa.

Głuchowski J., 2006, Polskie prawo podatkowe, Wydawnictwo Prawnicze Lexis Nexis, Warszawa.

Jaszczyński M., 217, Funkcje podatków w gospodarce, „Zeszyty Naukowe PWSZ w Płocku. Nauki Ekonomiczne", Państwowa Wyższa Szkoła Zawodowa w Płocku, Płock.

Korenik D., Korenik S., 2004, Podstawy finansów, PWN, Warszawa.

Kozłowski P., 2004, Gospodarka nieformalna w Polsce. Dynamika i funkcje instytucji. Źródła formy występowania - wyjaśnienia, Instytut Nauk Ekonomicznych Polska Akademia Nauk, Ziggurat, Warszawa.

Kuchciak I., 2012, Raje podatkowe w zmniejszeniu obciażeń podatkowych, Wydawnictwo Uniwersytetu Łódzkiego, Łódź. 
Kurzac M., 2017, Uchylanie się od opodatkowania i oszustwo podatkowe w rozumieniu art. 54 i 56 Kodeksu karnego skarbowego w świetle odestań do systemu prawa podatkowego, „Studia Prawno-Ekonomiczne", Łódzkie Towarzystwo Naukowe, Łódź.

Łapiński K., Peterlik M., Wyżnikiewicz B., 2014, Szara strefa w polskiej gospodarce, Instytut Badań Nad Gospodarką Rynkową, Warszawa.

Łechtańska M., 2016, Klasyczne przestępstwo podatkowe - uchylanie się od opodatkowania, Prawo karne skarbowe - wybrane zagadnienia teorii i praktyki, Olsztyn.

Mara E. R., 2011, Causes and consequences of underground economy, Anale. Seria Stiinte Economice, Cluj-Napoca.

Marciniak S., 2013, Mikro- i makroekonomia. Podstawowe problemy współczesności, Wydawnictwo Naukowe PWN, Warszawa.

Masiukiewicz P., 2014, Czarny rynek a system płatności, „Kurier Finansowy”, nr 3(37).

Mizgajska H., 2002, Aktywność innowacyjna polskich matych $i$ średnich przedsiębiorstw w procesie integracji z Unia Europejska, Akademia Ekonomiczna w Poznaniu, Poznań.

Mróz B., 2004, Szara strefa a dylematy polityki gospodarczej, „Nierówności Społeczne a Wzrost Gospodarczy", nr 4.

Pasternak-Malicka M., 2016, Przestępstwa podatkowe w zakresie podatku od towarów i ustug $w$ świetle analiz organów podatkowych oraz własnych badań empirycznych, „Zeszyty Naukowe Uniwersytetu Szczecińskiego. Finanse, Rynki Finansowe, Ubezpieczenia”, nr 5(83).

Raczkowski K., 2013, Gospodarka nieoficjalna w systemie zarządzania państwem, „Przedsiębiorczość i Zarządzanie", t. XIV.

Rosser Jr, J. B., Rosser M. V., Ahmed E., 2000, Income inequality and the informal 20 economy in transition economies, „Journal of Comparative Economics”, Elsevier, Amsterdam.

Schneider F, Enste H. D., 2004, Shadow Economies: Size, Causes, and Consequences, „Journal of Economic Literature", Pittsburgh.

Szulc A., 2013, Przyczyny i skutki zatrudnienia nierejestrowanego w Polsce, CeDeWu, Warszawa. Ustawa z dnia 10 września 1999 r. Kodeks karny skarbowy (Dz.U. 1999, nr 83, poz. 930).

Ustawa z dnia 28 września 1991r. o kontroli skarbowej (Dz.U. 1991, nr 100, poz. 442).

Ustawa z dnia 6 marca 2018 r. Prawo przedsiębiorców (Dz.U. 2018, poz. 646).

Zychowicz A., 2017, Jednolity Plik Kontrolny jako nowa instytucja polskiego prawa podatkowego, „Zeszyty Naukowe Uniwersytetu Przyrodniczo-Humanistycznego w Siedlcach”, nr 114.

\title{
THE PHENOMENON OF GRAY ECONOMY IN POLAND - CAUSES, EFFECTS AND REDUCTION METHODS
}

\begin{abstract}
This article deals with general issue of unofficial economy, understood as any sort of attempts made to avoid the responsibility of paying taxes by the citizens. This phenomenon is inherent on every economy and can influence it in the positive and negative way, but unfortunately the negative impact is more significant. Taking this into the consideration, the government undertakes a variety of actions to decrease the range of the gray economy. The most essential
\end{abstract}


element, which affects the process of shaping the scale of the gray zone, is whether the citizens express a "silent consent" to these types of activities. This essay contains research on the level of tax morality among randomly chosen group of people, who are in their production age

Keywords: grey economy, taxes, tax frauds. 